\title{
PENGEMBANGAN MODEL BAHAN BELAJAR MANDIRI BERBASIS ANDRAGOGI UNTUK MENINGKATKAN KOMPETENSI PENDIDIK ANAK USIA DINI
}

\author{
Wenny Hulukati*
}

\begin{abstract}
This research aims at creating a model of self- learning materials to improve PAUD teacher's competence in facilitating and developing learning in early childhood education. The model to be developed based on andragogy approach consists of the learning and teaching materials, learning and teaching guidelines, and assessment and evaluation guidelines. To reach the research objectives. research and development method was employed. The data was collected through observation, interview, questionnaire, and test. Data analysis used qualitative analysis capturing the analysis of preliminary research data, the result of expert validation, and try out data. Quantitative analysis was also integrated in this study for the experiment data. The result of this study shows that the self learning materials developed in this research can improve the early childhood education teacher's competence in teaching and learning process. It is recommended therefore to use this andragogy principles based model of self learning package for early childhood education teachers.
\end{abstract}

Keywords: self learning materials, pedagogy principles, early childhood teacher's competence

\begin{abstract}
Penelitian ini bertujuan untuk menemukan model bahan belajar mandiri yang dapat meningkatkan kompetensi pendidik PAUD tentang pengembangan diri anak usia dini. Upaya yang ditempuh untuk mencapai tujuan tersebut adalah dengan mengembangkan model bahan belajar mandiri berbasis andragogi, yang terdiri dari materi ajar, panduan pembelajaran dan panduan evaluasi, sehingga setelah mempelajari bahan belajar mandiri tersebut akan terjadi peningkatan kompetensi pendidik PAUD tentang pengembangan diri anak usia dini. Pengembangan model bahan belajar mandiri ini dilakukan dengan menggunakan metode research and development. Hasil penelitian pengembangan menunjukkan model bahan belajar mandiri berbasis andragogi yang dikembangkan dapat meningkatkan kompetensi pedagogi dan profesional pendidik PAUD tentang pengembangan diri anak usia dini. Oleh karena itu, penelitian ini menyarankan menggunakan model paket belajar mandiri ini dipergunakan oleh guru-guru PAUD.
\end{abstract}

Kata-kata kunci: bahan belajar mandiri, prinsip-prinsip pedagogi, kompetensi pendidikan guru PAUD.

\section{PENDAHULUAN}

Penyelenggaraan PAUD di Kabupaten Bone Bolango, khususnya PAUD pendidikan formal terdiri atas tempat penitipan anak ( 0 - 2 tahun), kelompok bermain (2-4 tahun) dan satuan PAUD sejenis (0 - 6 tahun). Berkenaan dengan penyelenggaraan pendidikan anak usia dini, peran pendidik yang profesional sangat dibutuhkan. Profesionalitas yang dimaksudkan meliputi kompetensi pedagogi, sosial, kepribadian, dan profesional. Mengingat tingkat pendidik PAUD di Kabupaten Bone Bolango masih bervariasi antara sekolah dasar sampai sarjana, maka upaya-upaya peningkatan profesionalisme itu menjadi sangat penting.

* Dosen Jurusan Bimbingan Konseling Universitas Gorontalo
Upaya untuk meningkatkan kompetensi pendidik PAUD di Kabupaten Bone Bolango, khususnya kompetensi tentang pengembangan diri anak usia dini telah dilakukan melalui pelatihan-pelatihan, namun baru sekitar $47 \%$ yang telah mengikuti pelatihan dimaksud dan 53\% lainnya belum mengikuti pelatihan (hasil asessmen). Di samping itu, materi pelatihan belum mencakup aspek pengembangan diri anak usia dini secara keseluruhan. Masalah kurangnya pelatihan tersebut sebenarnya dapat diatasi melalui penyediaan bahan belajar/ buku-buku sumber yang dapat dipelajari secara langsung oleh pendidik PAUD.

Sebagai orang dewasa yang memiliki karateristik belajar, seperti memiliki kesiapan belajar, memiliki 
kemampuan/ keterampilan belajar, serta menginginkan dapat segera memanfaatkan hasil belajarnya, maka belajar melalui bahan belajar mandiri akan membantu meningkatkan kompetensi pendidik PAUD tentang pengembangan diri anak usia dini. Berdasarkan hasil asessment pada studi pendahuluan, pemanfaatan bahan belajar/buku-buku sumber yang tersedia di lembaga-lembaga pendidikan anak usia dini khususnya di Kabupaten Bone Bolango, oleh para pendidik PAUD belum dapat meningkatkan kompetensinya tentang pengembangan diri anak usia dini.

Beberapa faktor yang menyebabkan penggunaan bahan belajar tersebut belum dapat meningkatkan kompetensi pendidik PAUD tentang pengembangan diri anak usia dini adalah.

1. Bahan belajar/buku-buku sumber tentang pengembangan diri anak usia dini masih sangat terbatas, terutama dari segi cakupan aspek-aspek pengembangan diri anak usia dini yang harus dikembangkan.

2. Bahan belajar tersebut tidak dirancang sebagai bahan belajar mandiri, di mana pendidik PAUD dapat dengan mudah mempelajari cara-cara pengembangan diri anak usia dini. Dalam arti bahan belajar tersebut baru berupa bahan bacaan dan belum dilengkapi dengan petunjuk-petunjuk yang dapat memandu pendidik PAUD untuk mempelajarinya secara praktis dan mendalam.

3. Bahan belajar tersebut tidak dirancang dengan memperhatikan karateristik belajar orang dewasa serta belum memperhatikan prinsip-prinsip penyusunan bahan belajar mandiri.

4. Bahan belajar tersebut tidak dilengkapi dengan latihan-latihan praktis yang dapat segera dimanfaatkan oleh pendidik PAUD dalam melaksanakan tugasnya terkait dengan pengembangan diri anak usia dini.

5. Bahan belajar tersebut belum dikemas dengan penampilan yang menarik untuk memotivasi pendidik PAUD untuk mempelajarinya.

6. Belum ada model bahan belajar mandiri berbasis andragogi yang telah dikembangkan selama ini.

Mengacu pada beberapa permasalahan yang telah diutarakan sebelumnya, maka penelitian ini difokuskan pada permasalahan bagaimana model bahan belajar mandiri yang dapat meningkatkan kompetensi pendidik PAUD tentang pengembangan diri anak usia dini di Kabupaten Bone Bolango?

Untuk memperjelas penelitian ini, maka masalah yang diteliti dibatasi pada.

1. Bagaimanakah kondisi awal bahan belajar mandiri untuk meningkatkan kompetensi pendidik anak usia dini tentang pengembangan diri anak usia dini?

2. Bagaimanakah model konseptual bahan belajar mandiri berbasis andragogi yang dapat meningkatkan kompetensi pendidik PAUD tentang pengembangan diri anak usia dini ?

3. Bagaimanakah implementasi model bahan belajar mandiri berbasis andragogi yang dapat meningkatkan kompetensi pendidik PAUD tentang pengembangan diri anak usia dini ?

4. Bagaimanakah efektifitas model bahan belajar mandiri berbasis andragogi yang dapat meningkatkan kompetensi pendidik PAUD tentang pengembangan diri anak usia dini ?

Secara umum penelitian ini bertujuan untuk mengembangkan model bahan belajar mandiri berbasis andragogi untuk meningkatkan kompetensi pendidik PAUD. Berdasarkan tujuan umum tersebut, dirumuskan tujuan khusus penelitian ini, yakni untuk.

1. Mendeskripsikan kondisi awal bahan belajar mandiri dalam mengembangkan kompetensi pendidik PAUD tentang pengembangan diri anak usia dini.

2. Mengembangkan model konseptual bahan belajar mandiri berbasis andragogi untuk meningkatkan kompetensi pendidik PAUD tentang pengembangan diri anak usia dini.

3. Mengimplementasikan model bahan belajar mandiri berbasis andragogi untuk meningkatkan kompetensi pendidik PAUD tentang pengembangan diri anak usia dini.

4. Mengetahui efektifitas model bahan belajar mandiri berbasis andragogi untuk meningkatkan kompetensi pendidik PAUD tentang pengembangan diri anak usia dini.

\section{KAJIAN TEORETIS}

Andragogi sebagai Model Belajar Orang Dewasa

Secara etimologis, andragogi berasal dari bahasa Yunani yang terdiri dari dua kata andra yang artinya orang dewasa dan agogos yang artinya memimpin atau membimbing. Andragogi memiliki makna sebagai seni dan ilmu membantu orang dewasa belajar (Knowles,
1980: 38). Dalam makna yang lebih luas andragogi bukan sekedar membantu orang dewasa belajar tetapi membantu manusia belajar. Teori andragogi menggabungkan elemen psikologi humanistik dengan pendekatan sistem. Pembelajaran akan lebih bermakna jika melibatkan warga belajar sepenuhnya dan menekankan 
pengarahan diri (self-directed).

Pembelajaran orang dewasa akan berhasil dengan baik jika melibatkan warga belajar secara utuh baik fisik maupun mental emosionalnya. Oleh sebab itu, pelaksanaan pembelajaran yang bersifat andragogi sebaiknya mengikuti langkah-langkah berikut.

(1) Iklim belajar perlu diciptakan sesuai dengan keadaan orang dewasa; (2) peserta diikutsertakan mendiagnosa kebutuhan belajarnya; (3) peserta dilibatkan dalam proses perencanaan belajarnya; (4) proses pembelajaran merupakan tanggung jawab bersama antara fasilitator dan peserta; dan (5) evaluasi belajar dalam proses belajar secara andragogi menekankan kepada cara evaluasi diri sendiri.

\section{Pembelajaran dan Bahan Belajar Mandiri}

Pembelajaran mandiri (independent learning) merupakan bentuk kegiatan pembelajaran, di mana pengajar sebagai fasilitator sedangkan siswa belajar sendiri (Suparman, 1991: 174). Dalam pembelajaran mandiri siswa/warga belajar menggunakan bahan belajar yang didesain secara khusus. Menurut Mujiman (2007: 14), belajar mandiri dapat menggunakan paket-paket belajar yang berisi self instructional materials, buku teks, hingga teknologi informasi lanjut, dapat digunakan sebagai media belajar mandiri.

Penggunaan bentuk kegiatan instruksional pembelajaran mandiri ini mempunyai beberapa keuntungan yaitu.

a) Biaya pengajarannya tidak mahal, karena dapat diikuti oleh sejumlah besar siswa/warga belajar;

b) Siswa/warga belajar dapat maju menurut kecepatan masing-masing;

c) Bahan belajar dapat di-review dan direvisi secara bertahap, bagian demi bagian, untuk mengatasi halhal yang membingungkan atau kurang jelas dari siswa/ warga belajar;

d) Siswa/ warga belajar mendapat umpan balik secara teratur dalam proses belajarnya, karena telah terintegrasi dalam bahan belajar yang dipelajarinya.

Di samping memiliki keuntungan, bentuk kegiatan instruksional pembelajaran mandiri dalam bentuk bahan belajar mandiri ini mempunyai kekurangankekurangan sebagai berikut.

a) Tingginya biaya pengembangan bahan serta membutuhkan waktu yang lama;

b) Menuntut disiplin belajar yang tinggi yang mungkin kurang dimiliki oleh siswa/ warga belajar pada umumnya dan siswa/ warga belajar yang masih belum matang pada khususnya

c) Membutuhkan ketekunan yang lebih tinggi dari fasilitator untuk terus menerus memantau proses belajar siswa/ warga belajar, memberi motivasi dan konsultasi secara individual setiap waktu siswa/ warga belajar membutuhkannya. Ketekunan seperti itu tidak selalu dimiliki fasilitator yang telah biasa menjadi pengajar klasikal, sebagaimana model pembelajaran lainnya, penggunaan pembelajaran mandiri memerlukan persyaratan tertentu.

Bentuk pembelajaran mandiri ini tepat digunakan bila.

a) Didesain sesuai kebutuhan menampung sejumlah besar siswa/warga belajar dalam satu periode tertentu yang tidak mungkin diatasi dengan bentuk pengajaran regular atau kovensional.

b) Kekurangan tenaga pengajar untuk berfungsi sebagai pengajar regular.

c) Tersedia sejumlah tenaga pengembang instruksional yang mampu mengembangkan atau memproduksi bahan instruksional.

d) Kemampuan dan karakteristik siswa/warga belajar sangat heterogen sehingga tidak mungkin diberi pelajaran secara klasikal.

\section{Langkah-Langkah Penyusunan Bahan Belajar Mandiri}

Menyusun bahan belajar mandiri membutuhkan aktivitas khusus dan harus melalui prosedur atau langkah-langkah yang sistematis, mengingat bahan belajar itu harus dapat digunakan siswa/ warga belajar secara mandiri. Untuk memproduksi bahan belajar mandiri, penyusun perlu melakukan langkah-langkah sebagai berikut.

1 Memilih dan mengumpulkan bahan belajar/ materi yang tersedia di lapangan dan relevan dengan isi bahan belajar mandiri yang akan disusun. Bahanbahan tersebut dapat berbentuk buku, bab tertentu dalam buku, atau program media audiovisual.

2 Mengadaptasikan bahan belajar/ materi tersebut kedalam bentuk bahan belajar mandiri dengan mengikuti strategi instruksional yang telah disusun sebelumnya. Bila ternyata tidak ada bahan belajar/ materi yang sesuai, penyusun harus mulai menulis bahan belajar sendiri.

3 Meneliti kembali konsistensi isi bahan belajar tersebut dengan strategi instruksional (pembelajaran) yang telah dirancang sebelumnya.

4 Meneliti kualitas teknis dari bahan tersebut, yang meliputi tiga hal berikut.

a) Bahasa yang sederhana dan relevan,

b) Bahasa yang komunikatif, dan

c) Desain fisik.

\section{Peran Pendidik Anak Usia Dini}

Menurut Rogers (dalam Catron dan Allen, 1999:58) keberhasilan pendidik PAUD yang sebenarnya menekankan pada tiga kualitas dan sikap yang utama, 
yaitu (1) pendidik yang memperhatikan kualitas perkembangan anak menjadi manusia seutuhnya; (2) membuat suatu pelajaran menjadi berharga dengan menerima perasaan anak-anak dan kepribadian, serta percaya bahwa yang lain pada dasarnya layak dipercaya membantu menciptakan suasana menyenangkan selama belajar; dan(3) mengembangkan pemahaman empati pada pendidik yang peka, sensitif, dalam mengenal anak.

Hymes, Read \& Patterson, Yardley (dalam Catron dan Allen, 1999 : 59) menyatakan pendidik yang baik untuk anak memilki ciri khas yaitu kehangatan hati, kepekaan, mudah beradaptasi, jujur, ketulusan hati, sifat yang bersahaya, sifat yang menghibur, menerima perbedaan individu, mampu mendukung pertumbuhan tanpa terlalu melindungi, badan yang sehat dan kuat, ketegaran hidup, perasaan kasihan, keharuan, menerima diri, emosi stabil, pecaya diri, mampu untuk terus menerus berprestasi, dan dapat belajar dari pengalaman.

Lebih spesifik peran pendidik/PAUD di antaranya peran pendidik dalam berinteraksi dalam usaha pengembangan diri anak usia dini adalah.

1) Peran pendidik dalam pengasuhan.
2) Peran pendidik dalam mengatur tekanan/stres.

3) Peran pendidik dalam memberikan fasilitas.

4) Peranan pendidik dalam perencanaan.

5) Peran pendidik dalam pengayaan.

6) Peran Pendidik dalam menangani masalah.

7) Peran pendidik dalam pembelajaran.

8) Peran pendidik dalam bimbingan dan pemeliharaan.

(a) Fngsi pemahaman yaitu usaha menghasilkan pemahaman pada anak tentang diri sendiri, lingkungan, dan cara menyesuaikan dengan pengembangan diri

(b) Fungsi pencegahan bimbingan yang menghasilkan tercegahnya anak didik dari berbagai permasalahan yang dapat mengganggu dan menghambat atau menimbulkan kesulitan-kesulitan dalam proses pengembangan diri anak

(c) Fungsi perbaikan yaitu bimbingan yang akan menghasilkan terpecahkan berbagai permasalahan yang dihadapi anak

(d) Fungsi pemeliharaan dan pengembangan yaitu bimbingan menghasilkan terpeliharanya dan berkembangnya berbagai potensi dan kondisi positif anak didik dalam rangka pengembangan dirinya secara mantap.

\section{METODOLOGI PENELITIAN}

Pendekatan yang digunakan dalam penelitian ini adalah pendekatan kualitatif dan kuantitatif. Pendekatan kualitatif digunakan dalam proses pengembangan model bahan belajar mandiri berbasis andragogi untuk meningkatkan kompetensi pendidik PAUD. Proses analisis ini memerlukan penjelasan tentang pendapat, keyakinan dan persepsi orang-orang tentang kegiatan, serta menganalisis kegiatan itu sendiri. Kegiatan yang dimaksud adalah kegiatan pengembangan model bahan belajar mandiri berbasis andragogi yang dapat meningkatkan kompetensi pendidik PAUD. Hal ini sesuai dengan pendapat Bog dan dan Bikken $(1982,2)$ yang menjelaskan bahwa tujuan penelitian kualitatif adalah untuk menerangkan dan menganalisis orang dan kumpulan dari kegiatan-kegiatan keyakinan, pikiran, dan persepsi dalam suatu kegiatan.

Dalam penelitian ini, dilakukan analisis terhadap pendapat para pakar terkait dengan validasi ahli/ pakar, yang meliputi (a) pakar PAUD, (b) pakar psikologi, (c) pakar desain, (d) pakar PLS, dan (e) pakar bahasa. Di samping itu, analisis kualitatif digunakan untuk menganalisis data uji coba lapangan skala kecil dan skala besar yang dilakukan oleh para pendidik PAUD.

Pendekatan kuantitatif digunakan dalam proses uji coba model bahan belajar mandiri yang telah dikembangkan, melalui penelitian eksperimen dalam hal ini quasi experiment. Eksperimen dilakukan untuk menguji efektifitas model bahan belajar mandiri yang dikembangkan, sehingga diperoleh model bahan belajar mandiri berbasis andragogi yang dapat meningkatkan kompetnsi pendidik PAUD dalam pengembangan diri anak usia dini.

Eksperimen yang digunakan adalah quasi experiment dengan desain nonrandomized control group pretest-posttest design (Michael, 1997:69). Yang digambarkan sebagai berikut.

Tabel 1 Desain Quasi Experiment

\begin{tabular}{|c|c|}
\hline Kelompol Eksperimen & Kelompok Kontrol \\
\hline $\mathrm{T} 1$ & $\mathrm{~T} 1$ \\
\hline $\mathrm{X}$ & - \\
\hline $\mathrm{T} 2$ & $\mathrm{~T} 2$ \\
\hline
\end{tabular}

Keterangan : $\mathrm{T}_{1}=$ Tes Awal (Pre test)

$\mathrm{T}_{2}=$ Tes Akhir (Post test)

$\mathrm{X}=$ Perlakuan (Treatment) 
Gambar di atas menunjukkan adanya dua kelompok yang dibentuk, yakni kelompok eksperimen dan kelompok kontrol. Pada kedua kelompok diberikan pretest dan posttest, tetapi hanya kelompok eksperimen yang diberikan perlakuan (treatment).

Prosedur penelitian dan pengembangan yang digunakan dalam penelitian ini adalah prosedur yang dikemukakan oleh Borg dan Gall (1989), yang dimodifikasi dalam bentuk enam langkah utama, yakni (1) analisis produk yang akan dikembangkan; (2) mengembangkan produk awal; (3) validasi ahli dan revisi; (4) uji coba lapangan skala kecil dan revisi produk; (5) uji coba lapangan skala besar dan; (6) revisi untuk mendapatkan produk akhir.

Data yang dibutuhkan dalam penelitian ini diperoleh dengan menggunakan teknik observasi, studi dokumen, wawancara, angket, dan tes.

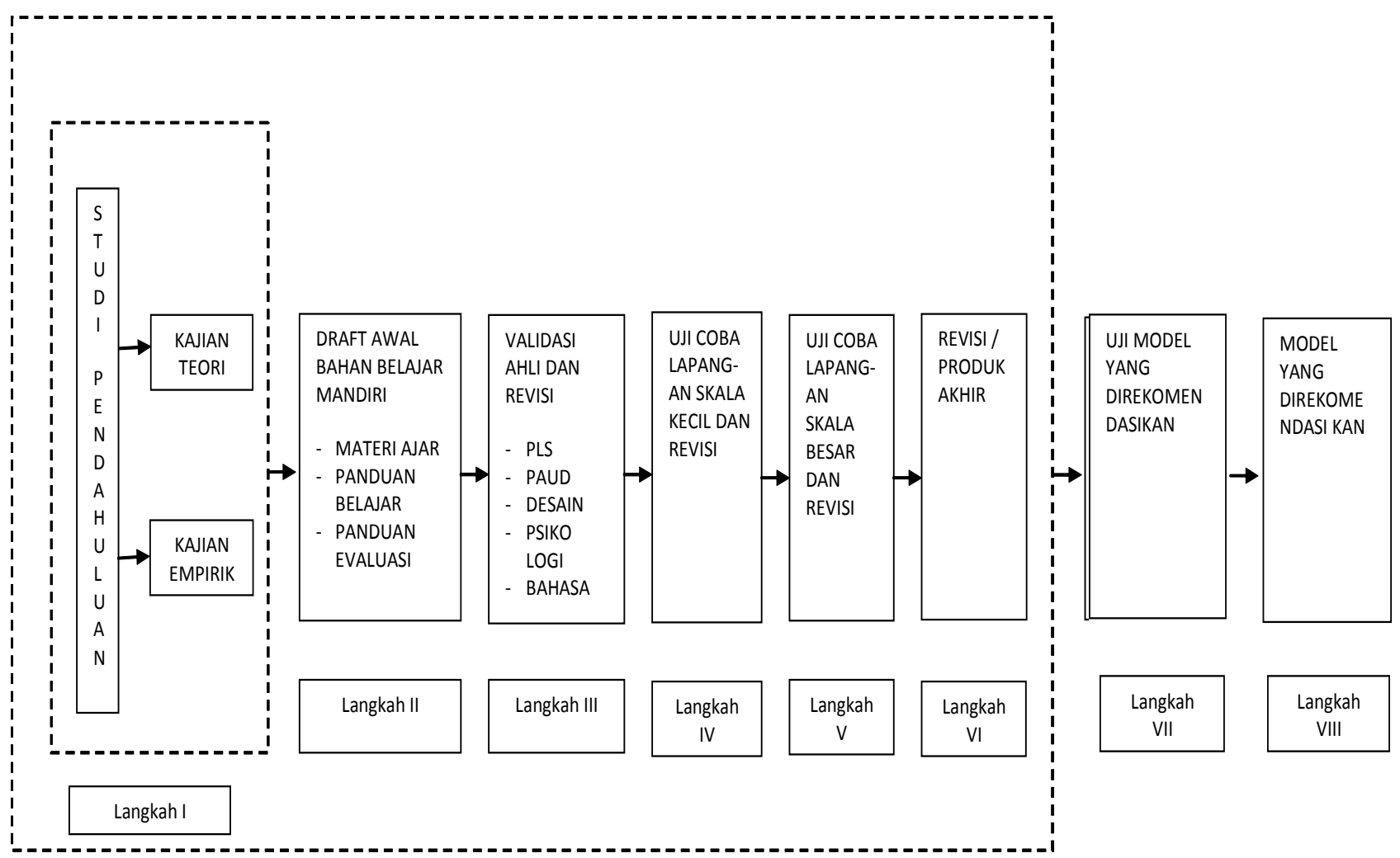

Gambar 1. Tahapan Penelitian

\section{HASIL PENELITIAN}

Analisis Kondisi Awal Bahan Belajar Mandiri untuk Meningkatkan Kompetensi Pendidik PAUD tentang Pengembangan Diri Anak Usia Dini

Hasil studi pendahuluan menunjukkan bahwa ketersediaan bahan belajar (dalam hal ini buku) yang dimaksud sangat terbatas, bahkan di beberapa PAUD tidak tersedia sama sekali. Data yang diperoleh melalui angket menunjukkan $12 \%$ responden menyatakan bahwa bahan belajar (buku) yang dapat dijadikan sumber bagi pendidik PAUD dalam upaya pengembangan diri anak usia dini tersedia dan $88 \%$ menyatakan tidak tersedia. Dari observasi ditemukan buku yang tersedia tersebut, meliputi Kreativitas Anak Usia Dini, dan Perkembangan dan Pembiasaan di Kelompok Bermain. Secara lebih rinci, kondisi awal bahan belajar (buku) yang dapat digunakan pendidik PAUD untuk membantu meningkatkan kompetensinya tentang pengembangan diri anak usia dini di PAUD Kabupaten Bone Bolango Provinsi Gorontalo, dapat digambarkan sebagai berikut.

a. Bahan belajar (buku) tentang pengembangan diri anak usia dini masih sangat terbatas, terutama dari segi cakupan aspek-aspek pengembangan diri anak usia dini yang harus dikembangkan.

b. Bahan belajar tersebut tidak dirancang sebagai bahan belajar mandiri, di mana pendidik PAUD dapat dengan mudah mempelajari cara-cara pengembangan diri anak usia dini. Dalam arti bahan belajar tersebut baru berupa bahan bacaan dan belum dilengkapi dengan petunjuk-petunjuk yang dapat memandu pendidik PAUD untuk mempelajarinya secara praktis dan mendalam. 
c. Bahan belajar tersebut tidak dirancang dengan memperhatikan karateristik belajar orang dewasa serta belum memperhatikan prinsip-prinsip penyusunan bahan belajar mandiri.

d. Bahan belajar tersebut tidak dilengkapi dengan latihan-latihan praktis yang dapat segera dimanfaatkan oleh pendidik PAUD dalam melaksanakan tugasnya terkait dengan pengembangan diri anak usia dini. e. Bahan belajar tersebut belum dikemas dengan penampilan yang menarik untuk memotivasi pendidik PAUD untuk mempelajarinya.

f. Belum ada model bahan belajar mandiri berbasis andragogi yang telah dikembangkan selama ini.

Kondisi awal bahan belajar untuk meningkatkan kompetensi PAUD tentang pengembangan diri anak usia dini dapat digambarkan sebagai berikut.

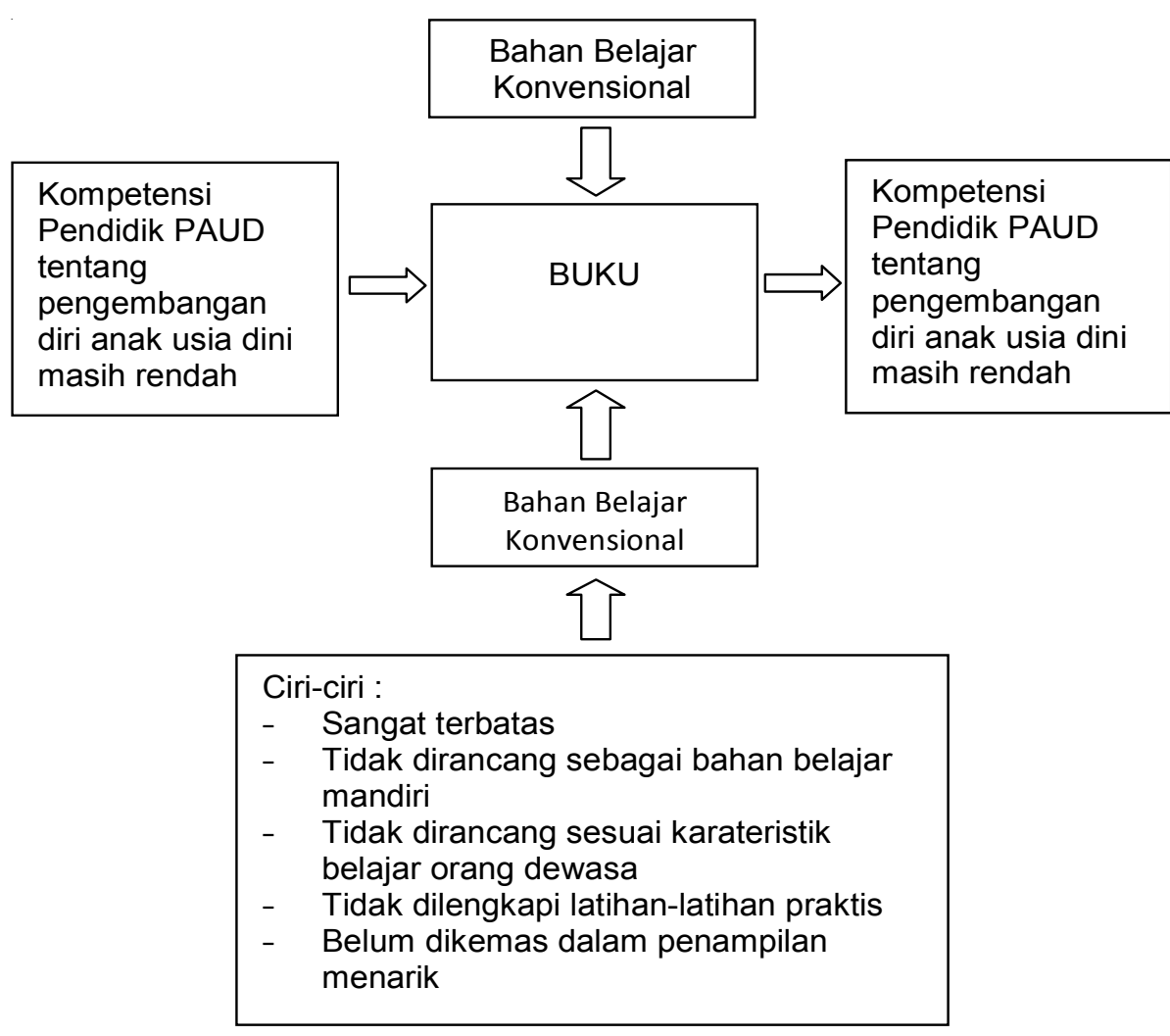

Gambar 2. Kondisi Awal Bahan Belajar Mandiri untuk Meningkatkan kompetensi Pendidik PAUD tentang Pengembangan Diri Anak Usia Dini

Pengembangan Model Konseptual Bahan Belajar Mandiri Berbasis Andragogi untuk Meningkatkan Kompetensi Pendidik PAUD tentang Pengembangan Diri Anak Usia Dini

Data tentang model konseptual bahan belajar mandiri berbasis andragogi untuk meningkatkan kompetensi pendidik PAUD tentang pengembangan diri anak usia dini diperoleh melalui validasi ahli terhadap model konseptual bahan belajar mandiri berbasis andragogi yang dikembangkan. Validasi dilakukan melalui (a) ahli pendidikan anak usia dini; (b) ahli psikologi; (c) ahli pendidkan luar sekolah; (d) ahli desain pembelajaran; dan (e) ahli bahasa.

Kegiatan validasi ini didahului oleh pengembangan model konseptual bahan belajar mandiri berbasis andragogi. Pengembangan ini diawali dengan mela- kukan kajian empiris dan kajian teoretis. Kajian empiris berupa kegiatan studi pendahuluan terhadap penyelenggaraan pendidikan PAUD di Kabupaten Bone Bolango Provinsi Gorontalo dalam upaya pengembangan diri anak usia dini yang meliputi kegiatan (a) mengkaji kondisi awal bahan belajar mandiri yang dapat digunakan pendidik PAUD dalam pengembangan diri anak usia dini; (b) mengkaji profil kompetensi pendidik PAUD; (c) mengkaji aktivitas pendidik PAUD dalam upaya pengembangan diri anak usia dini; (d) merumuskan kesimpulan hasil kajian empirik sebagai dasar pengembangan model bahan belajar mandiri berbasis andragogi untuk meingkatkan kompetensi pendidik PAUD tentang pengembangan diri anak usia dini. Kajian teoretis berupa kegiatan, (a) mengkaji konsep, model dan azas bahan belajar mandiri, konsep dan teori belajar 
dan pembelajaran orang dewasa, dan konsep kompetensi pendidik PAUD; (b) mengkaji hasil-hasil penelitian yang relevan dengan pengembangan model bahan belajar mandiri; (c) menganalisis dasar-dasar yuridis dan kebijakan penyelenggaraan PAUD khususnya di Provinsi Gorontalo; dan (d) menetapkan konsep dan teori pokok sebagai landasan pengembangan bahan belajar mandiri berbasis andragogi untuk meningkatkan kompetensi pendidik PAUD.

Berdasarkan hasil kajian empiris dan teoretis di atas, maka disusunlah model konseptual bahan belajar mandiri berbasis andragogi untuk meningkatkan kompetensi pendidik PAUD tentang pengembangan diri anak usia dini, yang terdiri dari (a) materi ajar; (b) panduan pembelajaran, dan (c) panduan evaluasi.

Berdasarkan data hasil uji coba lapangan kelompok besar oleh pendidik PAUD terhadap materi ajar, panduan pembelajaran, dan panduan evaluasi, maka dapat disimpulkan bahwa.

a) Hasil uji coba pemahamanan dan keterbacaan.

(1) Materi ajar tidak direvisi.

(2) Panduan pembelajaran tidak direvisi.

(3) Panduan evaluasi tidak direvisi.

b) Hasil uji coba penerapan model bahan belajar mandiri berbasis andragogi menunjukkan, secara umum responden dapat melaksanakan pembelajaran untuk pengembangan diri anak usia dini sesuai model bahan belajar mandiri berbasis andragogi yang telah dipelajarinya.

Hasil uji coba lapangan skala kecil dan skala besar sebagaimana dideskripsikan di atas dapat dijadikan dasar untuk menyimpulkan bahwa model bahan belajar mandiri berbasis andragogi untuk meningkatkan pendidik PAUD benar-benar telah siap untuk diuji keefektifannya.

Efektivitas Model Bahan Belajar Mandiri Berbasis Andragogi untuk Meningkatkan Kompetensi Pendidik PAUD tentang Pengembangan Diri Anak Usia Dini.

Uji efektivitas model bahan belajar mandiri berbasis andragogi yang dikembangkan, dilakukan melalui quasi experiment, dengan responden yang berjumlah 15 orang untuk kelompok eksperimen dan 15 orang untuk kelompok kontrol.

Perhitungan efektifitas dampak model bahan belajar mandiri berbasis andragogi terhadap peningkatan kompetensi pendidik PAUD tentang pengembangan diri anak usia dini dilihat dalam tiga keadaan yaitu (1) dampak pada peningkatan kompetensi pedagogi; (2) dampak pada peningkatan kompetensi profesional; dan

(3) dampak pada kompetensi pedagogi dan profesional. 1. Peningkatan Kompetensi Pedagogi
Berdasarkan hasil analisis data diperoleh temuan bahwa model bahan belajar mandiri berbasis andragogi memberikan pengaruh positif terhadap peningkatan kompetensi pedagogik pendidik PAUD tentang pengembangan diri anak usia dini. Analisis data menunjukkan $F_{\text {residu }}>F_{\text {tabel }}$ atau $64,1>7,68$.

2. Peningkatan Kompetensi Profesional Pendidik PAUD

Berdasarkan hasil analisis data diperoleh temuan bahwa model bahan belajar mandiri berbasis andragogi memberikan pengaruh positif terhadap peningkatan kompetensi profesional pendidik PAUD tentang pengembangan diri anak usia dini. Analisis data menunjukkan $F_{\text {residu }}>F_{\text {tabel }}$ atau 38,7 $>7,68$.

3. Peningkatan Kompetensi Pedagogi dan Profesional Pendidik PAUD

Berdasarkan hasil analisis data menunjukkan $\mathrm{F}_{\text {residu }}>\mathrm{F}_{\text {tabel }}$ atau 86,6 $>$ 7,68. Dengan demikian dapat disimpulkan bahwa model bahan belajar mandiri berbasis andragogi memberikan dampak pada peningkatan kompetensi pedagogik dan professional pendidik PAUD tentang pengembangan diri anak usia dini.

Pengujian efektivitas model bahan belajar mandiri berbasis andragogi melalui eksperimen, selanjutnya dilakukan melalui uji penerapan di lapangan dalam konteks yang lebih nyata, yakni mengamati langsung aktivitas pendidik PAUD dalam menerapkan model bahan belajar mandiri yang dihasilkan dalam pembelajaran di kelas.

Pengamatan difokuskan pada penyusunan $\mathrm{SKH}$ serta penerapan pembelajaran berdasarkan SKH yang telah disusun. Kegiatan ini dilakukan melalui observasi dan wawancara dengan para pendidik PAUD di lima PAUD yang telah ditetapkan, yakni PAUD Mandiri, PAUD Garuda, PAUD Kartini, PAUD Menara Laut, dan PAUD Patriotik

Hasil observasi dan wawancara menunjukkan bahwa Pendidik PAUD telah mengimplementasikan model bahan belajar mandiri berbasis andragogi yang telah dihasilkan dalam penelitian ini.

Berdasarkan hasil pengujian dampak model bahan belajar mandiri berbasis andragogi untuk meningkatkan kompetensi pendidik PAUD tentang pengembangan diri anak usia dini, yang menunjukkan bahwa model bahan belajar mandiri berbasis andragogi yang dikembangkan memberikan dampak terhadap peningkatan kompetensi pendidik PAUD tentang pengembangan diri anak usia dini, maka ditetapkan model bahan belajar mandiri berbasis andragogi yang dikembangkan patut direkomendasikan untuk digunakan dalam upaya peningkatan kompetensi pendidik PAUD tentang pengembangan diri anak usia dini. 
Model bahan belajar mandiri berbasis andragogi untuk meningkatkan kompetensi pendidik PAUD tentang pengembangan diri anak usia dini yang direkomendasikan ini digambarkan sebagai berikut.

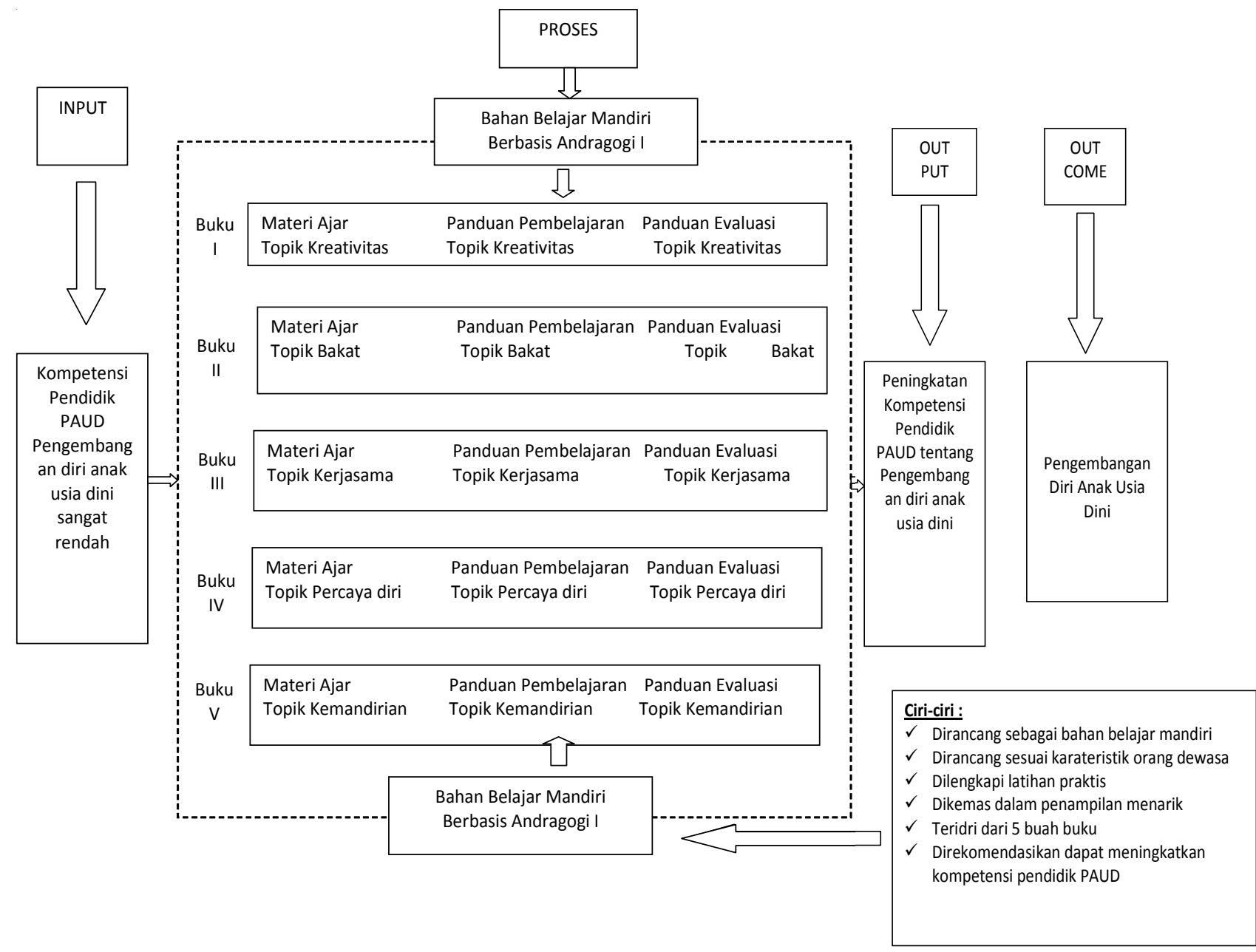

Gambar 3.Bahan Belajar Mandiri Berbasis Andragogi untuk Meningkatkan Kompetensi Pendidik PAUD tentang Pengembangan Diri Anak Usia Dini yang Direkomendasikan

Bagan di atas menunjukkan bahwa model bahan belajar mandiri berbasis andragogi yang direkomendasikan terdiri dari lima buku, di mana masing-masing buku terdiri dari tiga bagian, yakni materi ajar, panduan pembelajaran, dan panduan evaluasi.

\section{KESIMPULAN}

Kondisi bahan belajar mandiri untuk meningkatkan kompetensi pendidik PAUD tentang pengembangan diri anak usia dini di Kabupaten Bone Bolango Provinsi Gorontalo dapat ditunjukkan sebagai berikut (a) tidak dirancang sebagai bahan belajar mandiri; (b) tidak dirancang sesuai karateristik belajar orang dewasa; (c) tidak dilengkapi latihan-latihan praktis; dan (4) belum dikemas dalam penampilan yang dapat memotivasi pendidik PAUD untuk mermpelajarinya. Di samping itu, bahan belajar yang ada memiliki keterbatasan dari segi cakupan aspek-aspek pengembangan diri anak usia dini yang harus dikembangkan, serta ketersediaan ba- han belajar dimaksud sangat terbatas.

Model konseptual bahan belajar mandiri berbasis andragogi yang dapat meningkatkan kompetensi pendidik PAUD tentang pengembangan diri anak usia dini, terdiri dari tiga bagian yakni materi ajar, panduan belajar dan panduan evaluasi. Setiap bagian terdiri dari lima topik (buku), sehingga terdapat 15 buku yakni

a. Materi ajar (1) Buku 1, topik kreativitas; (2) Buku 2, topik bakat; (3) Buku 3, topik kerjasama; (4) Buku 4, topik percaya diri, dan (5) Buku 5, topik kemandirian.

b. Panduan belajar (1) buku 1, panduan belajar topik 
kreativitas, (2) buku 2, panduan belajar topik bakat, (3) buku 3, panduan belajar topik kerjasama, (4) buku 4, panduan belajar topik percaya diri , dan (5) buku 5, panduan belajar, topik kemandirian.

c. Panduan evaluasi (1) buku 1, panduan evaluasi topik kreativitas, (2) buku 2, panduan evaluasi topik bakat, (3) buku 3, panduan evaluasi topik kerjasama, (4) buku 4, panduan evaluasi topik percaya diri; dan (5) buku 5, panduan evaluasi, topik kemandirian.

Implementasi model belajar mandiri berbasis andragogi yang dapat meningkatkan kompetensi pendidik PAUD tentang pengembangan diri anak usia dini, menghasilkan produk akhir bahan belajar mandiri berbasis andragogi untuk meningkatkan kompetensi pendidik PAUD tentang pengembangan diri anak usia dini yang tervalidasi, teridirdari lima buku, yakni.

a. Buku 1: Materi ajar, topik kreativitas

b. Buku 2: Materi ajar, topik bakat

c. Buku 3: Materi ajar, topik kerjasama

d. Buku 4: Materi ajar, topik percaya diri

e. Buku 5: Materi ajar. topik kemandirian

Model bahan belajar mandiri berbasis andragogi yang dikembangkan melalui penelitian ini ternyata efektif dalam meningkatkan kompetensi pendidik PAUD tentang pengembangan diri anak usia dini. Hal ini ditun- jukkan oleh adanya peningkatan kompetensi pendidik PAUD, baik kompetensi pedagogi maupun kompetensi professional setelah menggunakan model bahan belajar mandiri berbasis andragogi yang dikembangkan melalui penelitian ini, sebagai berikut (a) peningkatkan kompetensi pedagogik menunjukkan $\mathrm{F}_{\text {residu }}>\mathrm{F}_{\text {tabel }}$ atau 64,1 $>7,68$; (b) peningkatkan kompetensi professional menunjukkan $\mathrm{F}_{\text {residu }}>\mathrm{F}_{\text {tabel }}$ atau 38,7>7,68; (c) peningkatkan kompetensi pedagogik dan professional menunjukkan $F_{\text {residu }}>F_{\text {tabel }}$ atau 86,6 7,68.

Temuan dalam penelitian ini menunjukkan bahwa model bahan belajar mandiri berbasis andragogi yang dikembangkan ini teruji efektif dalam meningkatkan kompetensi pedagogi dan profesional pendidik PAUD tentang pengembangan diri anak usia dini. Dengan demikian maka model bahan belajar mandiri berbasis andragogi yang dikembangkan ini patut direkomendasikan untuk digunakan pihak-pihak terkait dalam upaya meningkatkan kompetensi pedagogi dan profesional pendidik PAUD tentang pengembangan diri anak usia dini.

Selain itu hasil penelitian ini direkomendasikan lebih lanjut melalui penelitian dengan subjek penelitian yang lebih luas serta metode eksperimen yang sesungguhnya (true experiment).

\section{DAFTAR PUSTAKA}

Abdulhak, I. (2000). Metodologi pembelajaran orang dewasa. Bandung: CV. Andira.

Berk, L.E. \& Winsler,A. (1995). Scafolding children learning; Vygotsky and early chilhood education. Washington DC: NAEYC.

Borg, W.R. \& Gall, M.D. (1983). Educational research : An introduction. London. Longman, Inc.

Burhasman. (2008). Pelayanan konseling di sekolah dalam pengembangan diri siswa. (makalah disampaikan pada konversi nasional II latan Konselor Indonesia (IKI) dan Seminar Internasional Konseling di Padang 30-31 Maret 2008.

Cranton, P.A (1992). Working with adult learners. Toronto. Wall \& Emersen, Inc.

Catron \& Allen. (1999). Early childhood curiculum; $A$ creative play model edition. Newyersey: Meril Publ.

Cremer \& Siregar, M.F. (1993). Permainan dan latihan dinamika kelompok proses pengembangan diri. Jakarta: Gramedia.

Dick, W.,\& Carey, L. (1990). The systematic design of instruction. Third Edition. New York: Harper
Collins Publisher.

Finger, M. \& Asun, J.M. (2004). Quo vadis pendidikan orang dewasa (alih Bahasa : Nining Fatikasari). Yogyakarta : Pustaka Kendi.

Goleman, D. (1999). Kecerdasan emosional. Alih Bahasa, T. Hermaya. Jakarta: Gramedia

Hurlock, E.B. (1978). Chlid development. Six education. Mc Graw-Hill, Inc.

Kartono, K. (1996). Psikologi umum, Bandung: Mandar Maju.

Knowles, M.S. (1980). The adult learner : A neglegted species houston. Gulf Publishing Couparman: Atwi.

Mappa, S \& Basleman. (1994). Teori belajar orang dewasa. Jakarta: Dedikbud, Dirjen Pendidikan Tinggi.

Masa, S. (2005). Seni dan teknik fasilitasi pendidikan orang dewasa. Bandung: Y-Pin Indonesia.

Mitrani, A. \& Fitt, D. (1992). Competency based human resource management, value-driven strategis for recruitment, development and reward, kogan page limited. London.

Mujiman, H. (2007). Manajemen pelatihan berrbasis 
belajar mandiri. Yogyakarta: Pustaka Pelajar.

Munandar, S.C. (1992). Mengembangkan bakat dan kreativitas anak sekolah: Petunjuk bagi para guru dan orang tua. Jakarta: PT. Gramedia.

Rahmat, A. (2008). Andragogi: IImu dan seni belajar orang dewasa. Sukabumi: PATLOT Cendekia Press.

Rusman. (2010). Model-model pembelajaran: Mengembangkan profesionalisme guru. Jakarta: Rajawali Press.

Sevilla, G., et all. (1993). Pengantar metode penelitian. Penerjemah Alimudin Turu. Jakarta: UI-Press.

Siagian, S.P (1989). Teori motivasi dan aplikasinya. Jakarta: Bina Aksara.

Spencer, M.L., \& Spencer, M.S. (1993). Competence at work: Models for superrior performance, John New York: Wily and Son. Inc.

Sugiyono. (2008). Metode penelitian kuantitatif, kualitatif dan $R \& D$. Jakarta: CV. Alfabeta.
Sujiono, Y. (2009). Konsep dasar pendidikan anak usia dini. Jakarta: PT. Indeks.

Sukardi. (2005). Metodologi penelitian pendidikan: Kompetensi dan paktiknya. Jakarta: PT. Bumi Aksara.

Suparman, A. (1991). Desain instuksional. Jakarta: PAU UT.

Suryadi, A. (2009). Mewujudkan masyarakat pembelajar: Konsep, kebijakan dan Implementasi. Bandung: Widya Aksara Press

Taruh, E. (2003). Konsep diri dan motivasi berprestasi dan kaitannya dengan hasil belajar fisika. Jurnal Penelitian Pendiidkan, Vol IV (8). hal15-29.

Taqiyuddin, M. (2008). Pendidikan untuk semua: Dasar dan falsafah pendidikan luar sekolah. Bandung: Mulia Press.

Yusuf, S. (2003). Program bimbingan dan konseling di sekolah. (SLTP dan SLTA). Bandung: Pustaka Quraisy. 